${ }^{1}$ Assist. Prof., Maltepe University, İstanbul, Turkey,

denizozbay@maltepe.edu.tr

ORCID: 0000-0003-4643-7577

Submitted: $22 / 05 / 2021$

Revised: 4/07/2021

Accepted: 30/07/2021

Online Published: 25/09/2021

Citation: Özbay, D., Sustainable supply chain management and financial performance: An empirical analysis of Turkish manufacturing companies, bmij (2021) 9 (3): 908-921, doi: https://doi.org/10.15295/bmij.v9i3.1846

\section{Sustainable supply chain management and financial performance: An empirical analysis of Turkish manufacturing companies}

\section{Sürdürülebilir tedarik zinciri yönetimi ve finansal performans: Türk imalat işletmelerinin ampirik bir analizi}

\author{
Deniz Özbay ${ }^{1}$
}

\begin{abstract}
The linkage between sustainable supply chain management (SSCM) and financial performance has attracted increasing interest from both researchers and practitioners. Although many have argued that the SSCM practices improve financial performance, empirical studies have produced mixed results, and the direction of the relationship is still unclear. This study examined the relationship between SSCM and financial performance for Turkish manufacturing companies. Financial performance was measured using ROA, ROE and price to book ratio, while SSCM performance was measured with a new multivariable performance indicator. Financial performance data were obtained from the Bloomberg Database, while SSCM data were collected from non-financial reports using content analysis. The total sample included 47 manufacturing companies listed in Borsa İstanbul, covering 584 firm-year observations for 2007-2019. Panel data regression analysis was used to test the relationship between SSCM and financial performance. Similar to the literature's general view, the findings support a positive linear relationship between SSCM and firm financial performance.
\end{abstract}

Keywords: Sustainability, Supply Chain Management, Financial Performance

Jel Codes: L25, M14, M49

Öz

Sürdürülebilir tedarik zinciri yönetimi (STZY) ve finansal performans arasındaki ilişki, hem araștırmacılar hem de uygulayıcılar için artan bir ilgi uyandırmaktadır. Çoğu çalışma, STZY uygulamalarının finansal performansı iyileştirdiğini iddia etse de, ampirik çalışmalarda karma sonuçlar elde edilmiș olup ilişkinin yönü belirsizliğini korumaktadır. Bu çalışma, Türk imalat şirketleri için STZY ile finansal performans arasındaki ilişkiyi incelemektedir. Finansal performans ROA, ROE ve piyasa değeri/defter değeri oranı kullanılarak ölçülürken, STZY performansı çok değişkenli yeni bir performans göstergesi ile ölçülmüştür. Finansal performans verileri Bloomberg veri tabanından elde edilirken, STZY verileri, içerik analizi kullanılarak, şirketlerin finansal olmayan raporlarından elde edilmiştir. Araştırma örneklemi, Borsa İstanbul'da işlem gören 47 imalat şirketine ait 2007-2019 yılı arasındaki 584 veriyi içermektedir. STZY ile finansal performans arasındaki ilişkiyi test etmek için panel veri regresyon analizi kullanılmış olup, literatürdeki genel görüşe benzer şekilde, bulgular STZY ile şirketlerin finansal performansı arasında pozitif doğrusal ilişkiyi desteklemektedir.

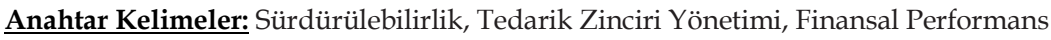

JEL Kodları: L25, M14, M49 


\section{Introduction}

Although sustainability and supply chain management (SCM) issues have been separately discussed for many years, the increasing interest in SCM sustainability practices in academia and businesses is relatively new. Before moving on to the reasons for this increased interest, it is necessary to look at both concepts. SCM is "the systemic, strategic coordination of the traditional business functions and the tactics across these business functions within a particular company and across businesses within the supply chain, to improve the long-term performance of the individual companies and the supply chain as a whole" (Mentzer, DeWitt, Keebler, Min, Nix, Smith, and Zacharia 2001, p.18). The supply chain involves all activities associated with the flow of goods and information from raw materials to the enduser. On the other hand, SCM integrates these activities through improved supply chain relationships to achieve sustainable competitive advantage. Sustainable supply chain management (SSCM) integrates a sustainability-based management approach to all parts of the supply chain process.

The concept of sustainability was first emphasized in the Brundtland Report of the World Commission on Environment and Development. The report defined it as "considering the needs of today without compromising the needs of future generations" (WCED, 1987). From a business sustainability perspective, the other most famous description of sustainability is the "triple-bottom-line" (TBL) approach of John Elkington (1998), which includes managing economic, social, and environmental dimensions in organizations. However, earlier studies mostly considered sustainability in terms of the environmental responsibilities of businesses besides their economic goals, whereas TBL emphasizes social responsibility alongside environmental and economic responsibilities. As a result, TBL has become recognized as the generally accepted viewpoint of business sustainability issues, as in SSCM (Zailani, Jeyaraman, Vengadasan, and Premkumar, 2012; Seuring, 2013; Paulraj, Chen, and Blome, 2017; Wang and Dai, 2018). According to Carter and Rogers (2008, p. 368), SSCM is "the strategic, transparent integration and achievement of an organisation's social, environmental, and economic goals through the systemic coordination of key inter-organizational business processes". Similarly, Seuring (2013, p. 1514) define SSCM as "the management of material, information and capital flows as well as cooperation among companies along the supply chain while integrating goals from all three dimensions of sustainable development". Both definitions include three critical dimensions of SSCM: cooperation among all partners in the supply chain; equal importance of the three dimensions (TBL) of sustainability; and exceptional attention to stakeholder participation.

Like corporate sustainability studies, earlier SSCM studies were primarily based on the environmental perspective of sustainability and were titled green supply chain management (GSCM). Today, although it is accepted that SSCM is based on three dimensions: social, economic and environmental, it is seen that these two concepts are still used interchangeably. On the other hand, Ahi and Searcy (2013) analyzed 34 published definitions of green supply chain management (GSCM) and SSCM and concluded that definitions for GSCM are more narrowly focused than those for SSCM. While GSCM definitions generally include an environmental, flow, and coordination focus, SSCM definitions also have an economic and social focus, while GSCM and SSCM have stakeholder and long-term focus. Thus, they argued that SSCM is essentially an extension of GSCM. However, their results also show that none of the studied definitions addresses all the identified characteristics of business sustainability and SCM. They, therefore, proposed a new definition of SSCM (Ahi and Searcy, 2013, p. 229): “The creation of coordinated supply chains through the voluntary integration of economic, environmental, and social considerations with key inter-organizational business systems designed to efficiently and effectively manage the material, information, and capital flows associated with the procurement, production, and distribution of products or services in order to meet stakeholder requirements and improve the profitability, competitiveness, and resilience of the organization over the short- and long-term."

Firms in both developed and emerging economies are paying increasing attention to environmental initiatives in the supply chain (Esfahbodi, Zhang, and Watson, 2016, p. 350). Companies, therefore, implement SSCM through environmental programs and social practices that involve all supply chain members (Wang and Dai, 2018, p.3). One of the fundamental reasons for this growing attention on SSCM is its strategic importance for companies. As Markley and Davis (2007) note, it is increasingly important to have a sustainable supply chain strategy because of the future challenge to develop a sustainable global economy. So, companies should evaluate their supply chains' impact on their social/ethical and environmental performance, in addition to financial performance, from having successful supply chain partnerships (Markley and Davis, 2007, p. 764). In addition, many studies in the literature have examined the relationship between GSCM/SSCM and company financial performance. These studies find that SSCM practices can increase employee morale, customer goodwill, and sound 
managerial practices by improving relationships with stakeholders. That is, environmental and social responsiveness are positively related to firm performance.

On the other hand, today's companies are under constant pressure from stakeholders, including customers, employees, NGOs, governments, and other regulatory bodies, to engage environmental and social practices (Zhu and Sarkis, 2007; Zhu, Sarkis, and Lai, 2013; Amjad, Jamil, and Ehsan, 2017). In addition, they are increasingly demanding that companies manage the environmental impacts of their supply chains more effectively (Paulraj et al., 2017, p. 239-240). Otherwise, companies that ignore these pressures may face reputational risk (Roehrich, Grosvold, and Hoejmose, 2014). So, stakeholders' internal and external pressures are another vital factor for increasing attention to SSCM practices.

In the literature, many studies examined the relationship between SSCM and organizational performance. Although the results support a predominantly positive relationship, the direction of the relationship is still unclear. While many of these studies used questionnaire surveys for data collection, few studies used publicly available data. Furthermore, few studies use time series, and therefore, most studies do not take into account the variation of the relationship over time. This paper examines the relationship between SSCM and financial performance with a publicly available objective data set covering 13 years. In addition, the study aims to contribute to the literature and lead for future studies, as it is the first study to investigate the relationship between SSCM and FP in Turkish manufacturing companies with panel data analysis.

In this study, the theoretical background and early studies related relationship between SSCM and organizational performance are discussed in the first section. Afterwards, conceptual models and working hypotheses are developed based on the literature and findings of previous studies. Then, the findings obtained from the empirical analyses are reported. Finally, the results are discussed, and suggestions for future research are given in the last section.

\section{Literature review and hypothesis development}

\section{Theoretical background and early studies}

Several theories can explain the relationship between corporate social/environmental performance and financial performance, including stakeholder theory, good management theory, institutional theory, (natural) resource-based theory, slack resource theory and risk management theory. One of the most commonly used theories explaining the link between SSCM practices/performance and corporate performance is the resource-based view (RBV) (Golicic and Smith, 2013, p. 81). Although, in the literature, it has long been accepted that competitive advantage depends on coordination between organizational (internal) capabilities and dynamic environmental (external) conditions; RBW, which deals with the relationships between firm resources, capabilities and competitive advantage, is relatively new (Hart, 1995, p. 987). The theory suggests that the combination of different resources and their management affects the firm's capabilities. Businesses can provide a competitive advantage if the resources are valuable and inimitable and have no equivalent substitution (Sarkis, Zhu, and Lai 2011, p. 8; Golicic and Smith, 2013, p. 81).

On the other hand, Hart (1995) argued that RBV ignores the challenges and constraints imposed by the (natural) environment. Therefore, he suggested Natural RBV, which assumes that future competitive advantage is based on "capabilities that facilitate environmentally sustainable economic activity". The strategic capability of Natural RBV requires three interconnected strategies: pollution prevention, product stewardship, and sustainable development, while "key resources and capabilities also affect the ability of the firm to sustain its competitive advantage" (Hart, 1995, p. 991). According to Natural RBV, a resource or capability must have specific characteristics to create a sustainable competitive advantage. For example, it must be valuable and non-substitutable, implicit, socially complex, or rare. In other words, if a firm's environmental strategies are based on distinctive (cost-to-copy) resources or capabilities, this external orientation may reinforce and differentiate the firm's position through the positive effects of a good reputation. Thus, this theory aligns with the previously discussed triple bottom line strategy, which focuses on an organisation's environmental, social, and financial components (Markley and Davis, 2007, p. 769). Because resource-based theories support a link between corporate capabilities and competitive advantage, they are considered appropriate to explain the relationship between SSCM and corporate performance (Golicic and Smith, 2013, p.82).

While RBV and Natural RBV emphasize a combination of resources and explain how these can improve capabilities, slack resources theory emphasizes resource limitations. It argues that companies with spare resources tend to invest in corporate social practices like SSCM. This view is often based on the belief that companies can only engage in corporate social responsibility activities if their financial performance 
is strong and they have enough financial resources. Conversely, companies with fewer financial resources reduce corporate social responsibility activities (Waddock and Graves, 1997, p. 306). Ortas, Moneva, and Álvarez (2014) examined the link between SSCM and financial performance for a sample of 3,900 companies covering 2004-2011, using multivariate measures of SSCM performance and financial performance. They found a unidirectional relationship between SSCM performance and profitability but a general bidirectional causality for company margins and revenue. In addition, they found that financial performance indicators influence companies' SSCM performance during periods of stability and crisis. Thus, their results are consistent with slack resources theory.

According to good management theory, which is based on the stakeholder view (Freeman, 1984), good management practices and engaging in corporate social responsibility activities improve relationships with key stakeholders. The strong relationship between stakeholders reduces cost and risk, provides a competitive advantage and better reputation, and improves corporate performance (Waddock and Graves, 1997, p. 307). For example, a good employee relationship can provide moral motives, productivity and satisfaction. In addition, consideration of social issues and customer expectations can increase positive perceptions about the firm. These may increase sales and reduce stakeholder management costs (Waddock and Graves, 1997, p. 307). In addition to the expectation that participating in social and environmental activities will increase the interaction with all company stakeholders, encourage sound management practices, and improve financial performance by using resources more effectively and efficiently, various factors affect a company's decision to engage social and environmental practices. Roehrich et al. (2014, p. 695) argue that reputational risk is vital for implementing social and environmental practices like SSCM. Previous studies have often emphasized the strategic role of corporate social and environmental responsibility practices. According to risk management theory, companies prefer to improve socially or environmentally friendly practices to avoid reputational risk and enhance the corporate image (Godfrey, 2005). Therefore, most companies are also under pressure to improve their environmental performance (Pagell, Yang, Krumwiede, and Sheu 2004, p. 30). Thus, stakeholder pressures are important motivating forces to engage in SSCM practices. According to institutional theory, external pressures push a company to engage in organizational practices. For example, governance regulations and laws have improved environmental awareness in both developed and developing countries. Furthermore, increasing expectations and pressure of both the market and customers also drive companies to improve social and environmental practices (Sarkis et al., 2011, p. 7).

Zhu and Sarkis (2007) examined the relationships between GSCM practice, environmental performance and economic performance, incorporating three moderating factors: the market, regulatory, and competitive institutional (internal) pressures. They reported that competitive pressure significantly increases the economic benefits, whereas the institutional pressures do not improve or reduce economic performance, while eco-design practice adoption decreases organizational, economic benefits when there are market pressures. Similarly, Zhu et al. (2013) examined the mediating effect of internal and external green SCM practices on the relationship between institutional pressures and organizational (environmental, economic, and operational) performance based on data for 396 Chinese manufacturing companies. They found that green SCM practices do not directly affect economic performance but can improve it indirectly. Like Zhu et al. (2013), Paularj et al. (2017) examined the mediating role of SSCM on corporate performance by considering moral motives as a critical driver for organizational SSCM. Thus, they examined the mediating effect of SSCM practices on the relationship between corporate motives (instrumental, relational, and moral) and corporate performance (environmental and financial performance). They found a positive relationship between SSCM practices and corporate performance, and SSCM fully mediates the performance outcomes of both relational and moral motives.

Whether based on RBV theory, stakeholder theory, or good management theory, many studies have reported that environmental and social practices improve company financial performance. For example, Golicic and Smith (2013) conducted a meta-analysis of 31 studies with 77 independent effect sizes to determine the overall effect of environmental supply chain practices/performance on firm performance. They found a significant positive relationship between environmental supply chain practices and market-based, operational-based, and accounting-based forms of firm performance. However, while many studies show a direct or indirect positive link between SSCM and financial performance, others suggest a negative relationship. For example, Kim and Rhee (2012) used structural equation modelling to examine the impact of GSCM critical success factors on balanced scorecard performance for 249 Korean companies. They found a negative relationship between several critical GSCM factors and financial performance. 
Similarly, Esfahbodi et al. (2016) investigated the link between SSCM and environmental and cost performance in emerging economies by comparing Chinese and Iranian companies. Their results suggested that the adoption of SSCM practices improves environmental performance, although the relationship between SSCM practices and cost performance was primarily negative. Furthermore, Similar to Zhu et al. (2013) and Paularj et al. (2017), Amjad et al. (2017) also examined the mediating effects of SSCM on organizations' motives and organizational performance. However, they found a negative direct relationship between SSCM and financial performance and showed that SSCM practices significantly mediate the relationship between organizational motives and organizational performance. Therefore, it is seen that the results of studies examining the relationship between SSCM and financial performance may differ significantly from each other. Table 1 summarizes some necessary studies and their findings.

Table 1: Early studies and their findings

\begin{tabular}{|c|c|c|c|c|c|c|}
\hline Study & Year & $\begin{array}{l}\text { Sample } \\
\text { Size }\end{array}$ & $\begin{array}{l}\text { Financial } \\
\text { Performance } \\
\text { Indicator } \\
\end{array}$ & Data Collection & Methods & Findings \\
\hline Zhu et al. & 2005 & 314 & $\begin{array}{l}\text { Negative and } \\
\text { positive cost } \\
\text { performance }\end{array}$ & Questionnaire & Factor analysis & $\begin{array}{l}\text { No significant } \\
\text { relationship for FP }\end{array}$ \\
\hline $\begin{array}{l}\text { Rao and } \\
\text { Holt }\end{array}$ & 2005 & 52 & $\begin{array}{l}\text { Profit margin, sales, } \\
\text { market share. }\end{array}$ & Questionnaire & $\begin{array}{l}\text { Structural } \\
\text { equation } \\
\text { modelling (SEM) }\end{array}$ & Positive relationship \\
\hline $\begin{array}{l}\text { Zhu and } \\
\text { Sarkis }\end{array}$ & 2007 & 341 & $\begin{array}{l}\text { Negative and } \\
\text { positive cost } \\
\text { performance }\end{array}$ & Questionnaire & $\begin{array}{l}\text { Hierarchical } \\
\text { multiple } \\
\text { regression analysis }\end{array}$ & $\begin{array}{l}\text { No significant } \\
\text { relationship for FP }\end{array}$ \\
\hline $\begin{array}{l}\text { Zailani et } \\
\text { al. }\end{array}$ & 2012 & 106 & $\begin{array}{l}\text { Sales, market share, } \\
\text { cost performance, } \\
\text { efficiency }\end{array}$ & Questionnaire & $\begin{array}{l}\text { Multiple linear } \\
\text { regression analysis }\end{array}$ & Positive relationship \\
\hline Zhu et al. & 2012 & 396 & Cost performance & Questionnaire & $\begin{array}{l}\text { Hierarchical } \\
\text { multiple } \\
\text { regression analysis }\end{array}$ & Positive relationship \\
\hline $\begin{array}{l}\text { Kim and } \\
\text { Rhee }\end{array}$ & 2012 & 249 & $\begin{array}{l}\text { ROE, improving in } \\
\text { profit, smoothed } \\
\text { cash flow, increased } \\
\text { rate of earnings and } \\
\text { sales }\end{array}$ & Questionnaire & SEM & Negative relationship \\
\hline $\begin{array}{l}\text { Wang and } \\
\text { Sarkis }\end{array}$ & 2013 & 411 & ROA, ROE & $\begin{array}{l}\text { Bloomberg } \\
\text { Environment, } \\
\text { Social and } \\
\text { Governance (ESG) } \\
\text { database (2009- } \\
\text { 2011) }\end{array}$ & $\begin{array}{l}\text { Ordinary least } \\
\text { squares regression }\end{array}$ & $\begin{array}{l}\text { Long term positive } \\
\text { relationship }\end{array}$ \\
\hline $\begin{array}{l}\text { Ortas et } \\
\text { al. }\end{array}$ & 2014 & 3900 & $\begin{array}{l}\text { Efficiency, } \\
\text { Profitability, } \\
\text { Revenue }\end{array}$ & $\begin{array}{l}\text { ASSET4 ESG } \\
\text { database (2004- } \\
\text { 2011) }\end{array}$ & $\begin{array}{l}\text { Granger causality } \\
\text { tests. }\end{array}$ & $\begin{array}{l}\text { Bidirectional positive } \\
\text { relationship }\end{array}$ \\
\hline $\begin{array}{l}\text { Esfahbodi } \\
\text { et al. }\end{array}$ & 2016 & 128 & Cost performance & Questionnaire & $\begin{array}{l}\text { Multiple linear } \\
\text { regression analysis }\end{array}$ & Mixed results \\
\hline $\begin{array}{l}\text { Amjad et } \\
\text { al. }\end{array}$ & 2017 & 360 & $\begin{array}{l}\text { ROA, EBIT, Profit as } \\
\text { percentage of sales }\end{array}$ & Questionnaire & SEM & $\begin{array}{l}\text { No significant } \\
\text { relationship for FP }\end{array}$ \\
\hline $\begin{array}{l}\text { Paularj et } \\
\text { al. }\end{array}$ & 2017 & 259 & $\begin{array}{l}\text { ROA, EBIT, Profit as } \\
\text { percentage of sales }\end{array}$ & Questionnaire & SEM & Positive relationship \\
\hline $\begin{array}{l}\text { Wang and } \\
\text { Dai }\end{array}$ & 2018 & 172 & $\begin{array}{l}\text { ROA, ROS, ROI, } \\
\text { Improving in profit, } \\
\text { market share, } \\
\text { Reducing } \\
\text { environmental } \\
\text { damage }\end{array}$ & Questionnaire & $\begin{array}{l}\text { Partial least } \\
\text { squares (PLS) }\end{array}$ & $\begin{array}{l}\text { No significant } \\
\text { relationship for FP }\end{array}$ \\
\hline \multirow{2}{*}{$\begin{array}{l}\text { Tamayo- } \\
\text { Torres et } \\
\text { al. } \\
\text { Prasad et } \\
\text { al. }\end{array}$} & 2019 & 432 & Tobin Q & $\begin{array}{l}\text { Sustainalytics } \\
\text { database (2008- } \\
\text { 2010) }\end{array}$ & PLS based SEM & $\begin{array}{l}\text { Indirect positive } \\
\text { relationship }\end{array}$ \\
\hline & 2020 & 145 & Profitability & Questionnaire & SEM & Positive relationship \\
\hline
\end{tabular}

\section{Hypothesis development}

Although, as reviewed above, many studies have concluded that SSCM improves corporate financial performance, the relationship between them remains unclear. That is, numerous studies suggest that SSCM practices reduce costs (Bowen, Cousins, Lamming, and Faruk, 2001; Pagell, et al., 2004; Zailani et 
al., 2012) and risk (Rao and Holt, 2005; Gouda and Saranga, 2018), enhance productivity, growth and market value (Tamayo-Torres, Gutierrez-Gutierrez, and Ruiz-Moreno, 2019) and raise profitability (Prasad, Pradhan, Gaurav, and Sabat, 2020; Wang and Sarkis, 2013). On the other hand, some other studies have found no significant relationship between the two variables (Wang and Dai, 2018) or no evidence that SSCM improves economic performance (Zhu, Sarkis, and Geng, 2005; Ortas et al., 2014). Furthermore, some other studies indicate that SSCM practices impose additional costs (Min and Galle, 1997; Esfahbodi et al., 2016) and can cause a competitive disadvantage (Kim and Rhee, 2012), especially in the short term (Krause, Vachon, and Klassen 2009; Wang and Sarkis, 2013). Given these conflicting findings, the study is based on the following central hypothesis: There is a significant relationship between SSCM and financial performance.

\section{Theoretical model}

While definitions of SSCM give equal importance to all three dimensions - environmental, social and economical, the environmental dimension has played a determining role in studies measuring SSCM performance, whereas the social dimension is almost completely ignored or interpreted oversimplistically (Seuring, 2013, p. 1518). In this study, SSCM performance includes social performance criteria as well as economic and environmental ones. Figure 1 outlines the conceptual model of the study.

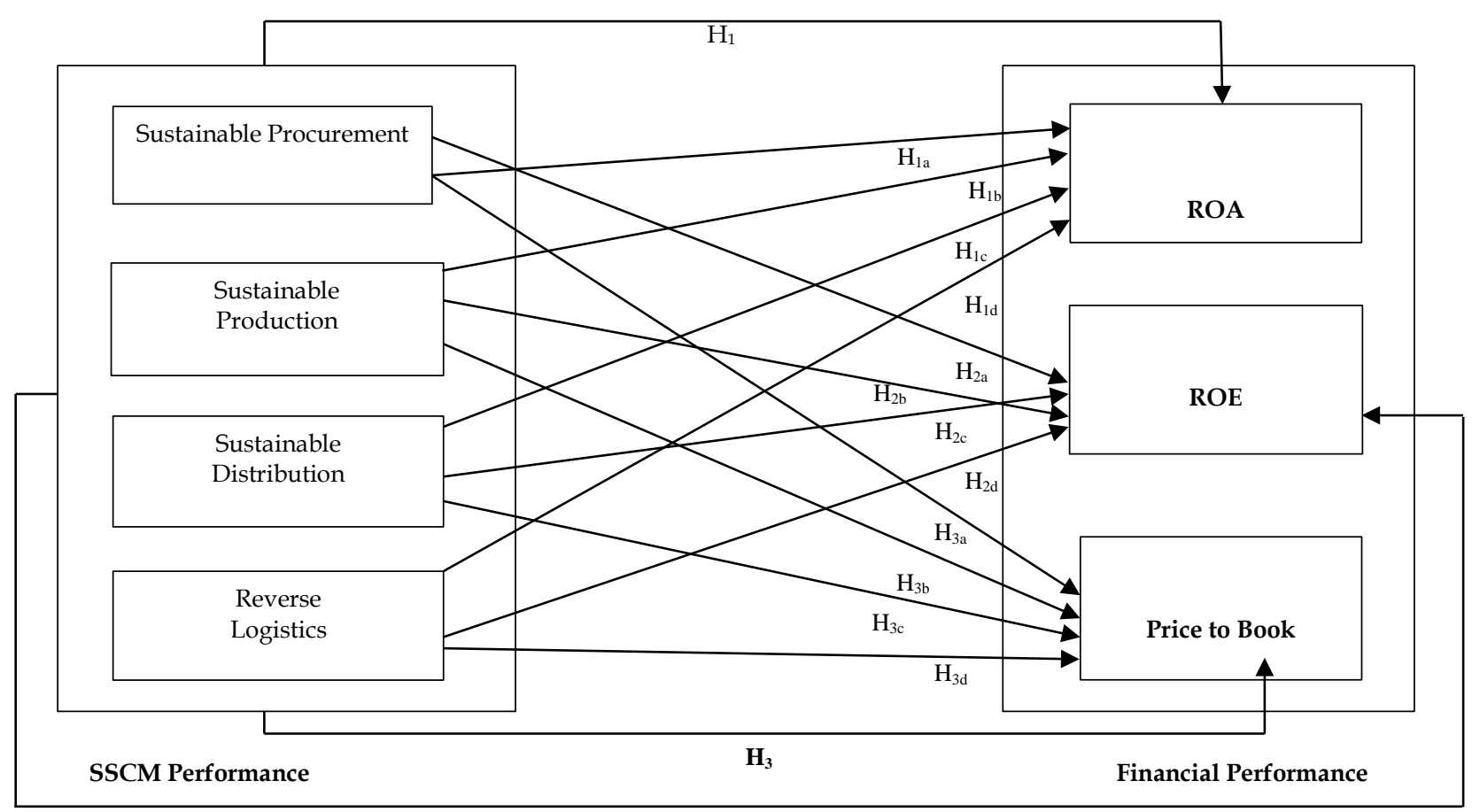

Figure 1: Theoretical Model

$\mathrm{H}_{2}$

As Figure 1 shows, SSCM performance is represented by four main variables: sustainable procurement (Zhu et al., 2005; Esfahbodi et al., 2016), sustainable production (Zhu et al., 2005; Wang and Dai, 2018), sustainable distribution (Zailani et al., 2012; Esfahbodi et al., 2016), and reverse logistics (Mann, Kumar, Kumar, and Mann, 2010). Sustainable procurement refers to supplier relations and purchasing policies. Sustainable production includes processes from sustainable design to distribution activities. Sustainable distribution refers to the sustainable transportation of products and services from manufacturers to customers. Sustainable distribution focuses on customer relationships, product stewardship, and green marketing. Finally, reverse logistics cover recovery, recycling, and reuse practices. While return on assets (ROA) and equity (ROE) are included in the study as accounting-based performance indicators, the price to book ratio represents the market-based performance. The following sub-hypotheses were formed to test the hypothesis of the significant relationship between SSCM and firm financial performance.

$\mathrm{H}_{1}=$ There is a significant relationship between SSCM and ROA (Model 1)

\footnotetext{
$\mathrm{H}_{1 \mathrm{a}}=$ There is a significant relationship between Sustainable Procurement and $R O A$

$\mathrm{H}_{1 \mathrm{~b}}=$ There is a significant relationship between Sustainable Production and ROA
} 
$\mathrm{H}_{1 \mathrm{c}}=$ There is a significant relationship between Sustainable Distribution and ROA

$\mathrm{H}_{1 \mathrm{~d}}=$ There is a significant relationship between Reverse Logistics and ROA

$\mathrm{H}_{2}=$ There is a significant relationship between SSCM and ROE (Model 2)

$\mathrm{H}_{2 \mathrm{a}}=$ There is a significant relationship between Sustainable Procurement and ROE

$\mathrm{H}_{2 \mathrm{~b}}=$ There is a significant relationship between Sustainable Production and $R O E$

$\mathrm{H}_{2 \mathrm{c}}=$ There is a significant relationship between Sustainable Distribution and ROE

$\mathrm{H}_{2 \mathrm{~d}}=$ There is a significant relationship between Reverse Logistics and ROE

$\mathrm{H}_{3}=$ There is a significant relationship between SSCM and Price/Book (Model 3)

$\mathrm{H}_{3 \mathrm{a}}=$ There is a significant relationship between Sustainable Procurement and Price/Book

$\mathrm{H}_{3 \mathrm{~b}}=$ There is a significant relationship between Sustainable Production and Price/Book

$\mathrm{H}_{3 \mathrm{c}}=$ There is a significant relationship between Sustainable Distribution and Price/Book

$\mathrm{H}_{3 \mathrm{~d}}=$ There is a significant relationship between Reverse Logistics and Price/Book

\section{Methodology}

\section{Sample selection}

The sample was selected from manufacturing companies listed on the Borsa Istanbul (Istanbul Stock Exchange) BIST100 index, which is the primary indicator for measuring the performance of the top 100 stocks in terms of market and trading volume. Because of missing data, the final sample included 47 out of 55 manufacturing companies listed in the BIST 100 index, providing 584 firm-year observations. Of these 47 companies, 24 were also indexed in the BIST Sustainability Index, launched in November 2014, with 58 companies, including 28 manufacturing. Hence, the final sample included the most sustainable manufacturing companies in Turkey. In addition, financial data was extracted from the Bloomberg Database, while SSCM data was collected using content analysis from the companies' sustainability, integrated, or annual reports for 2007-2019.

\section{Research design and measures of variables}

To test the hypotheses, the following panel regressions were estimated:

$$
\begin{aligned}
& \text { ROA }_{\mathrm{i}, \mathrm{t}}=\mathrm{a}_{0}+\beta_{1} \text { SSCMPerformance }_{\mathrm{i}, \mathrm{t}}+\beta_{2} \text { Leverage }_{\mathrm{i}, \mathrm{t}}+\beta_{3} \text { Size }_{i, t}+\beta_{4} \text { Industry }_{i, t}+\beta_{4}+\varepsilon_{\mathrm{i}, \mathrm{t}}(1) \\
& \text { ROE }_{\mathrm{i}, \mathrm{t}}=\mathrm{a}_{0}+\beta_{1} \text { SSCMPerformance }_{\mathrm{i}, \mathrm{t}}+\beta_{2} \text { Leverage }_{\mathrm{i}, \mathrm{t}}+\beta_{3} \text { Size }_{i, t}+\beta_{4} \text { Industry }_{i, t}+\beta_{4}+\varepsilon_{\mathrm{i}, \mathrm{t}}(2) \\
& \text { Price/Book }_{\mathrm{i}, \mathrm{t}}=\mathrm{a}_{0}+\beta_{1} \text { SSCMPerformance }_{\mathrm{i}, \mathrm{t}}+\beta_{2} \text { Leverage }_{\mathrm{i}, \mathrm{t}}+\beta_{3} \text { Size }_{i, t}+\beta_{4} \text { Industry }_{i, t}+\beta_{4}+\varepsilon_{\mathrm{i}, \mathrm{t}}
\end{aligned}
$$

ROA and ROE were chosen as the dependent variables in Model 1 and Model 2 because they are a widely adopted measure of accounting-based performance in the field of social responsibility and sustainability studies (Barnett and Salomon, 2012: 1308). ROA was measured as net income divided by total assets, while ROE was measured as net income divided by common equity. The price-to-book ratio represents market-based financial performance as the dependent variable of model 3 (Pava and Krausz, 1996, p. 338). It was measured as the average market price of shares divided by the book value of shares. Since the dependent variable is financial performance in all three models, it is necessary to control the factors that can affect financial performance systematically. Many studies consider firm size as a potential factor influencing financial performance (Waddock and Graves, 1997, p. 309; Lo and Sheu, 2007, p. 352). Therefore, size was added to the model as a control variable, and it was measured as the natural $\log$ of total assets. In addition, many studies have argued that a firm's capital structure impacts financial performance (Lo and Sheu, 2007, p. 352). Therefore, leverage was also added to the model as a control variable, and it was measured as total liabilities divided by common equity. Besides size and leverage, the industry has been an essential variable, impacting companies' social and financial 
relationships (Andersen and Dejoy, 2011, p. 251). Although this study covers only manufacturing enterprises, there are significant differences between sub-sectors that affect financial performance and companies' social and environmental disclosures. For example, businesses with significant environmental impact, such as cement and petrochemistry, can participate in more sustainability practices or make more social and environmental disclosures to overcome the negative perception of society (Brammer and Millington, 2008, p. 1331). Forty-seven companies included in this study were divided into six sub-sectors: food, beverage and tobacco, metal, energy, petrochemistry, glass and textile. The industry was determined one-digit codes from 1 to 6 and added to the model as a dummy variable.

The SSCM performance variables (sustainable procurement, sustainable production, sustainable distribution, and reverse logistics) were measured by 42 performance indicators, as listed in Appendix A. Each criterion was collected by content analysis and scored from 0 to 1 or 2 points for each company, then normalized over the total score before inclusion in the model. Thus, a new scale was created to measure SSCM performance. In addition, both SSCM and financial performance variable consists of publicly available data. Therefore, ethics committee approval is not required for the study. Table 2 shows the descriptive statistics of the independent variables.

Table 2: Descriptive statistics of the independent variables

\begin{tabular}{|l|lllll|}
\hline Variable & Obs & Mean & Std. Dev. & Min & Max \\
\hline \hline sprocurement & 592 & 3.244932 & 2.040821 & 0 & 8 \\
sproduction & 591 & 14.85787 & 5.894562 & 3 & 25 \\
sdistrubition & 592 & 2.586149 & 1.907154 & 0 & 8 \\
reverselog & 592 & 1.983108 & 1.290228 & 0 & 4 \\
sscmperf & 592 & 22.65878 & 9.942225 & 3 & 41 \\
leverage & 586 & 3.219889 & 13.53667 & 1.0609 & 293.6922 \\
Size & 589 & 7.451937 & 1.319531 & 3.860599 & 10.64022 \\
Industry & 595 & 2.52437 & 1.518903 & 1 & 6 \\
\hline
\end{tabular}

A few companies in the sample had considerably lower disclosure levels about their SSCM practices. Therefore, the scores for sustainable procurement, sustainable distribution, and reverse logistics started from 0 . On average, companies disclosed the most about sustainable production and the least about reverse logistic practices.

\section{Empirical analysis and results}

Panel data regression analysis was performed to test the relationship between SSCM and financial performance with the Stata 15. Before testing hypotheses, model specification tests were performed. According to the results of the F test, the individual effect was determined for all models (prob $>$ chi2 $=$ 0,0000). Then, the Hausman test was performed to choose between fixed effects and random effects. Since the p-values were less than 0,05 and significant for all models, the fixed-effect model was preferred to the random-effects model. In addition, the variance inflation factors (VIFs) had been calculated to determine multicollinearity. VIFs higher than 10 indicate serious multicollinearity problems in the measurement model (Hair, Anderson, Tatham, and Black, 1995). However, since VIFs ranged from 1.00 to 1.66 in all models, there was no multicollinearity problem. Finally, a modified Wald test for GroupWise heteroskedasticity was performed in the fixed-effects model (Baum, 2001). According to Wald Test, the results supported the heteroskedasticity problem $(\mathrm{P}<0.05)$. Finally, to determine autocorrelation, Modified Bhargava et al. Durbin-Watson and Baltagi-Wu LBI tests were performed. Because the values of the Durbin-Watson and Baltagi-Wu tests were less than 2, there was an auto-correlation problem. Since heteroskedasticity and auto-correlation problems, Driscoll and Kraay's (1998) fixedeffect estimator was preferred to test each hypothesis. Their methodology proposes a nonparametric covariance matrix estimator, which produces heteroscedasticity and autocorrelation-consistent standard errors robust to general spatial and temporal dependence (Hoechle, 2007, p. 282). In addition, it can be used with both balanced and unbalanced panel datasets. Table 3 summarizes the results of the analysis. 
Table 3: Results of the empirical analysis

\begin{tabular}{|c|c|c|c|c|c|c|}
\hline & \multicolumn{2}{|c|}{ MODEL 1} & \multicolumn{2}{|c|}{ MODEL 2} & \multicolumn{2}{|c|}{ MODEL 3} \\
\hline Variables & \multicolumn{2}{|c|}{ ROA } & \multicolumn{2}{|c|}{ ROE } & \multicolumn{2}{|c|}{ Price to Book } \\
\hline & $\mathrm{t}$ & $P>|t|$ & $\mathrm{t}$ & $P>|t|$ & $\mathrm{t}$ & $P>|t|$ \\
\hline Sprocurement & 1.13 & 0.265 & 2.04 & $0.047^{* *}$ & 5.51 & $0.000^{* * *}$ \\
\hline Leverage & -0.49 & 0.624 & -2.10 & $0.041^{* *}$ & 1.89 & 0.065 \\
\hline Size & -1.25 & 0.219 & -0.38 & 0.707 & -1.68 & 0.100 \\
\hline Industry & 2.36 & $0.022^{* *}$ & 1.17 & 0.250 & 2.77 & $0.008^{* * *}$ \\
\hline Sproduction & 2.68 & $0.010^{* * *}$ & 3.49 & $0.001^{* * *}$ & 4.90 & $0.000^{* * *}$ \\
\hline Leverage & -0.66 & 0.512 & -2.16 & $0.036^{* *}$ & 1.44 & 0.157 \\
\hline Size & -2.37 & $0.022^{* *}$ & -0.71 & 0.482 & -2.84 & $0.007^{* * *}$ \\
\hline Industry & 2.95 & $0.005^{* * *}$ & 1.14 & 0.262 & 3.12 & $0.003^{* * *}$ \\
\hline Sdistribution & 1.32 & 0.194 & 4.47 & $0.000^{* * *}$ & 6.89 & $0.000^{* * *}$ \\
\hline Leverage & -0.45 & 0.656 & -2.04 & $0.047^{* *}$ & 2.11 & $0.040^{* *}$ \\
\hline Size & -1.38 & 0.176 & -0.60 & 0.551 & -2.39 & $0.021^{* *}$ \\
\hline Industry & 2.58 & 0.013 & 1.30 & 0.201 & 3.40 & $0.001^{* *}$ \\
\hline ReverseLog & 1.89 & 0.065 & 1.84 & 0.072 & 0.43 & 0.666 \\
\hline Leverage & -0.50 & 0.619 & -2.19 & $0.034^{* *}$ & 1.86 & 0.069 \\
\hline Size & -1.53 & 0.134 & -0.28 & 0.780 & 0.62 & 0.542 \\
\hline Industry & 2.68 & $0.010^{* * *}$ & 1.08 & 0.285 & 0.99 & 0.328 \\
\hline SSCMPerf & 2.17 & $0,035^{* *}$ & 3.47 & $0.001^{* * *}$ & 4.52 & $0.000^{* * *}$ \\
\hline Leverage & -0.58 & 0.567 & -2.15 & $0.037^{* *}$ & 1.58 & 0.121 \\
\hline Size & -1.97 & 0.055 & -0.94 & 0.351 & -3.06 & $0.004^{* * *}$ \\
\hline Industry & 2.89 & $0.006^{* * *}$ & 1.39 & 0.170 & 3.74 & $0.001^{* * *}$ \\
\hline \multicolumn{7}{|c|}{${ }^{* *}$ and ${ }^{* * *}$ represent statistical significance at 5 per cent and 1 per cent levels. } \\
\hline \multicolumn{3}{|c|}{ Number of observations } & 584 & & & \\
\hline \multicolumn{3}{|c|}{ Number of groups } & 47 & & & \\
\hline
\end{tabular}

According to the results of model 1, overall SSCM performance and sustainable production had significant positive relationships with ROA. On the other hand, sustainable procurement, sustainable distribution and, reverse logistics had no significant relationships with ROA. In addition, according to the results of model 2, sustainable procurement, sustainable production, sustainable distribution, and overall SSCM performance had a significant positive impact on ROE. On the other hand, there was not fount a significant relationship between reverse logistics and ROE. Similar to model 2, the results in model 3 also supported positive relationships between the price/book ratio and all SSCM dimensions, except for reverse logistics. As a result, found that reverse logistics had no significant effect on financial performance. When the effect of SSCM on accounting performance and market performance was compared, it was found that SSCM had a more powerful impact on market performance. Although the relationship between total SSCM performance and financial performance measures was positive and significant in all three models, model 3 had higher $t$ values than others.

The results of this study support a positive linear relationship between SSCM and financial performance as consistent with the results of many empirical studies (Golicic and Smith, 2013). Furthermore, the results support the natural resource-based view that the central theoretical perspective testing the impact of environmental supply chain performance on financial performance (Ortas et al., 2014, p. 333). In addition, the results also support the excellent management theory, which argues that engaging in corporate social responsibility activities improves relationships with key stakeholders, provides a competitive advantage and improves corporate performance (Waddock and Graves, 1997, p. 307). Furthermore, the study findings also show that SSCM has a more powerful impact on market performance than accounting performance. Finally, the results are consistent with the positive relationship between corporate reputation and market value (Lo and Sheu, 2007). According to this view, sustainability practices increase the corporate reputation of businesses, encourage investors to invest in these companies, and the market values of companies with high sustainability performance are also positively affected. (Fombrun and Shanley, 1990). Table 4 summarizes the results of the hypotheses. 
Table 4: Results of the hypothesis tests

\begin{tabular}{|c|c|c|c|c|}
\hline Hypothesis & T values & $P>|t|$ & Coefficient & Result \\
\hline $\mathrm{H}_{1}$ & 2.17 & $0,035^{* *}$ & Positive & Supported \\
\hline$H_{1 a}$ & 1.13 & 0.265 & & Not Supported \\
\hline$H_{1 b}$ & 2.68 & $0.010^{* * *}$ & Positive & Supported \\
\hline $\mathrm{H}_{1 c}$ & 1.32 & 0.194 & & Not Supported \\
\hline$H_{1 d}$ & 1.89 & 0.065 & & Not Supported \\
\hline $\mathrm{H}_{2}$ & 3.47 & $0.001^{* * *}$ & Positive & Supported \\
\hline $\mathrm{H}_{2 a}$ & 2.04 & $0.047^{* *}$ & Positive & Supported \\
\hline $\mathrm{H}_{2 b}$ & 3.49 & $0.001^{* * *}$ & Positive & Supported \\
\hline $\mathrm{H}_{2 c}$ & 4.47 & $0.000^{* * *}$ & Positive & Supported \\
\hline $\mathrm{H}_{2 d}$ & 1.84 & 0.072 & & Not Supported \\
\hline $\mathrm{H}_{3}$ & 4.52 & $0.000^{* * *}$ & Positive & Supported \\
\hline $\mathrm{H}_{2 a}$ & 5.51 & $0.000^{* * *}$ & Positive & Supported \\
\hline $\mathrm{H}_{2 b}$ & 4.90 & $0.000^{* * *}$ & Positive & Supported \\
\hline $\mathrm{H}_{2 c}$ & 6.89 & $0.000^{* * *}$ & Positive & Supported \\
\hline $\mathrm{H}_{2 d}$ & 0.43 & 0.666 & & Not Supported \\
\hline
\end{tabular}

\section{Conclusions and recommendation}

Although the empirical literature generally indicates that SSCM and financial performance are positively related, this relationship is still ambiguous. While some results find a mixed or insignificant relationship, others show a negative relationship between SSCM and economic/financial performance. These inconsistencies may arise from differences in data sets regarding industry types, company sizes, sample size, customer behaviour, regularity regime, and cultural settings (Ortas et al., 2014, p. 335). Furthermore, the analysis and performance criteria used in the model can also affect the results (Wang and Sarkis, 2013, p. 874). Nevertheless, the results of this study support a positive linear relationship between SSCM and financial performance as consistent with the results of many empirical studies.

This study has some contributes to the sustainable supply chain literature. First of all, in literature, many empirical studies have used questionnaires to examine managerial perceptions of organizational performance, rather than using publicly available and objective data (Wang and Sarkis, 2013, p. 874). This study is one of the few studies based on publicly available objective data in the literature. In addition, only a few studies have included the time effect (Ortas et al., 2014; Tamayo-Torres et al., 2019). This study thus contributes to the literature as the first study on Turkish manufacturing companies to examine the relationship between SSCM and financial performance with panel data. Furthermore, although many of the studies in the literature describe SSCM as a combination of the economic, environmental, and social practices of companies, few studies (Wang and Dai, 2018) include social performance dimensions when assessing SSCM performance factors. Thus, this study also aims to contribute to the literature by proposing a new SSCM performance measurement model covering environmental and social dimensions.

On the other hand, the study has several limitations. First, there is no long-term sustainability performance database available for Turkish companies. In addition, many companies have published their corporate reports since 2006 or 2007 in Turkey. Since SSCM performance data was collected from corporate reports by content analysis, the study includes 13 years of data and sample size was limited because of the difficulty of measuring sustainability performance. Therefore, future research could use longer-term and larger data sets to investigate the long-run relationship between SSCM and financial performance. The second limitation is that this study only included large manufacturing companies. Small and medium-sized companies (SMEs) have fewer resources to invest in environmental and social practices than large companies, so their motivation to engage in SSCM practices differs. Therefore, future research could examine the performance of SMEs. Finally, future research could compare their findings with data from other emerging markets or developed countries to eliminate potential confounding effects of country, market size, and macroeconomic conditions.

\section{Peer-review:}

Externally peer-reviewed 


\section{Conflict of interests:}

The author(s) has (have) no conflict of interest to declare.

\section{Grant Support:}

The author(s) declared that this study has received no financial support

\section{References}

Ahi, P., and Searcy, C., (2013). A comparative literature analysis of definitions for green and sustainable supply chain management. Journal of Cleaner Production, 52, 329-341.

Amjad, M., Jamil, A., and Ehsan, A. (2017). The Impact of Organizational Motives on Their Performance with Mediating Effect of Sustainable Supply Chain Management. International Journal of Business and Society, 18(3), 585-602.

Andersen, M.L., and Dejoy, J.S. (2011). Corporate Social and Financial Performance: The Role of Size, Industry, Risk, R\&D and Advertising Expenses as Control Variables. Business and Society Review, 116 (2), 237-256.

Barnett, M. L., and Salomon, R. M. (2012). Does it pay to be really good? Addressing the shape of the relationship between social and financial performance. Strategic Management Journal, 33, 1304-1320.

Baum, C. F. (2001). Residual diagnostics for cross-section time series regression models. The Stata Journal, $1(1), 101-104$.

Bowen, F. E., Cousins, P. D., Lamming, R. C., and Faruk, A. C. (2001). Horse for courses: Explaining the gap between the theory and practice of green supply. Greener Management International, 9(3), 41-60.

Brammer, S., and Millington, A. (2008). Does it pay to be different? An analysis of the relationship between corporate social and financial performance. Strategic Management Journal, 29, 1325-1343.

Carter, R.C., and Rogers, D.S., (2008). A framework of sustainable supply chain management: Moving toward new theory. International Journal of Physical Distribution \& Logistics Management, 38 (5), 360387.

Driscoll, J., and Kraay, A. C. (1998). Consistent covariance matrix estimation with spatially dependent data. Review of Economics and Statistics, 80, 549-560.

Elkington, J. (1998). Accounting for The Triple Bottom Line. Measuring Business Excellence, 2(3), 18-22.

Esfahbodi, A., Zhang, Y., and Watson, G. (2016). Sustainable Supply Chain Management in Emerging Economies: Trade-Offs Between Environmental and Cost Performance. International Journal of Production Economics, 181 (2), 350-366.

Freeman, R.E. (1984). Strategic Management: A Stakeholder Perspective. Prentice-Hall, Englewood Cliffs, NJ.

Fombrun, C., and Shanley, M. (1990). What's in a name? Reputation building and corporate strategy. Academy of Management Journal, 33(2), 233-258.

Godfrey, P. C. (2005). The relationship between corporate philanthropy and shareholder wealth: A risk management perspective. Academy of Management Review, 30(4), 777-798.

Golicic, S. L., and Smith, C. D. (2013). A Meta-Analysis of Environmental Sustainable Supply Chain Management Practices and Firm Performance. Journal of Supply Chain Management, 49(2), 78-95.

Gouda, S. K., and Saranga, H. (2018). Sustainable supply chains for supply chain sustainability: Impact of sustainability efforts on supply chain risk. International Journal of Production Research, 56(17).

Hair, J. F. Jr., Anderson, R. E., Tatham, R. L., and Black, W. C. (1995). Multivariate Data Analysis (3rd ed). New York: Macmillan.

Hart, S. L. (1995). A Natural-Resource-Based View of the Firm. Academy of Management Review, 20 (4), 986-1014.

Hoechle, D. (2007). Robust standard errors for panel regressions with cross-sectional dependence. The Stata Journal, 7(3), 281-312. 
Kim, J., and Rhee, J. (2012). An Empirical Study on the Impact of Critical Success Factors on the Balanced Scorecard Performance in Korean Green Supply Chain Management Enterprises. International Journal of Production Research, 50(9), 2465-2483.

Krause, D.R., Vachon, S., and Klassen, R.D. (2009). Special Topic Forum on Sustainable Supply Chain Management: Introduction and Reflections on The Role of Purchasing Management. Journal of Supply Chain Management, 45, 18-25.

Lo, S., and Sheu, H. (2007). Is Corporate Sustainability a Value- Increasing Strategy for Business?. Corporate Governance, 15(2), 345-358.

Mann, H., Kumar, U., Kumar, V., and Mann, I. J. S. (2010). Drivers of Sustainable Supply Chain Management. The IUP Journal of Operations Management, 9(4), 52-63.

Markley, M.J. and Davis, L. (2007). Exploring future competitive advantage through sustainable supply chains. International Journal of Physical Distribution \& Logistics Management, 37 (9), 763-774.

Mentzer, J.T., DeWitt, W., Keebler, J.S., Min, S., Nix, N.W., Smith, C.D., and Zacharia, Z.G. (2001). Defining Supply Chain Management. Journal of Business Logistics, 22 (2), 1-25.

Min, H., and Galle, W.P. (1997). Green Purchasing Strategies: Trends and Implications. International Journal of Purchasing and Materials Management, 33, 10-17.

Ortas, E., M. Moneva, J., and Álvarez, I. (2014), Sustainable supply chain and company performance: A global examination. Supply Chain Management, 19(3), 332-350.

Pagell, M., Yang, C.-L., Krumwiede, D.W., and Sheu, C. (2004). Does the Competitive Environment Influence the Efficacy of Investments in Environmental Management?. Journal of Supply Chain Management, 40, 30-39.

Paulraj, A., Chen, J.I., and Blome, C., (2017). Motives and Performance Outcomes of Sustainable Supply Chain Management Practices: A Multi-theoretical Perspective. Journal of Business Ethics, 145, 239-258.

Pava, M. L., and Krausz, J. (1996). The Association Between Corporate Social-Responsibility and Financial Performance: The Paradox of Social Cost. Journal of Business Ethics, 15, 321-357.

Prasad, D.S., Pradhan, R.P., Gaurav, K., and Sabat, A.K. (2020). Critical Success Factors of Sustainable Supply Chain Management and Organizational Performance: An Exploratory Study. Transportation Research Procedia, 48, 327-344.

Rao, P., and Holt, D. (2005). Do Green Supply Chains Lead to Competitiveness and Economic Performance?. International Journal of Operations and Production Management, 25(9), 898-916.

Roehrich, J.K., Grosvold, J., and Hoejmose, S.U. (2014). Reputational risks and sustainable supply chain management: Decision making under bounded rationality. International Journal of Operations and Production Management, 34(5), 695-719.

Sarkis, J., Zhu, Q., and Lai, K. (2011). An organizational theoretic review of green supply chain management literature. International Journal of Production Economics, 130(1), 1-15.

Seuring, S. (2013). A review of modeling approaches for sustainable supply chain management. Decision Support Systems, 54, 1513-1520.

Tamayo-Torres, I., Gutierrez-Gutierrez, L., and Ruiz-Moreno, A. (2019). Boosting sustainability and financial performance: the role of supply chain controversies. International Journal of Production Research, 57(11), 3719-3734.

Waddock, S., and Graves, S. (1997). The corporate social performance - financial performance link. Strategic Management Journal, 18(4), 303-319.

Wang, j., and Dai, J., (2018). Sustainable supply chain management practices and performance. Industrial Management \& Data Systems, 118(1), 2-21.

Wang, Z., and Sarkis, J. (2013). Investigating the relationship of sustainable supply chain management with corporate financial performance. International Journal of Productivity and Performance Management, 62(8), 871-888.

WCED (World Commission on Environment and Development). (1987). Our Common Future. Oxford University Press, Oxford, UK. 
Zailani, S., Jeyaraman, K., Vengadasan, G. and Premkumar, R., (2012). Sustainable Supply Chain Management (SSCM) in Malaysia: A survey. International Journal of Production Economics, 140 (1), 330340 .

Zhu, Q., and Sarkis, J. (2007). The Moderating Effects of Institutional Pressures on Emergent Green Supply Chain Practices and Performance. International Journal of Production Research, 45, 4333-4355.

Zhu, Q., Sarkis, J., and Geng, Y. (2005). Green supply chain management in China: pressures, practices and performance. International Journal of Operations \& Production Management, 25(5), 449-468.

Zhu, Q., Sarkis, J., and Lai, K. H. (2013). Institutional-based Antecedents and Performance Outcomes of Internal and External Green Supply Chain Management Practices. Journal of Purchasing and Supply Management, 19, 106-117.

Zhu, Q., Sarkis, J., and Lai, K. H. (2012). Examining the Effects of Green Supply Chain Management Practices and Their Mediations on Performance Improvements. International Journal of Production Research, 50 (5), 1377-1394. 


\section{Appendix A: SSCM Dimensions of the Research}

\begin{tabular}{|c|c|}
\hline SSCM Criteria & References \\
\hline \multicolumn{2}{|l|}{ Sustainable Production } \\
\hline Social policies for employees & Wang and Dai, 2018 \\
\hline ISO 14001 certification & Zhu et al., 2005 \\
\hline Health and safety of employees (OHSAS 8001 certification) & Wang and Dai, 2018; Prasad et al., 2020 \\
\hline Sustainability training & Wang and Dai, 2018 \\
\hline \multicolumn{2}{|l|}{ ISO 9001 certification } \\
\hline Sustainable production strategy & Zhu, et al., 2005; Ortas, et al., 2014 \\
\hline Waste management & Pagell et al., 2004 \\
\hline Energy consumption rate & Esfahbodi et al., 2016 \\
\hline Carbon emissions rate & Esfahbodi et al., 2016 \\
\hline Environmentally friendly materials usage & Amjad et al., 2017 \\
\hline Sustainable product design & Zhu, et al., 2005; Amjad et al., 2017; Paularj et al., 2017 \\
\hline Environmental management system & Zhu et al., 2005 \\
\hline Sustainable process design & Ortas, et al., 2014; Amjad et al., 2017; Paularj et al., 2017 \\
\hline Sustainability production and process audit & Zhu et al., 2005; Wang and Dai, 2018 \\
\hline \multicolumn{2}{|l|}{ Renewable energy usage for production } \\
\hline Socially responsible management strategy & Wang and Dai, 2018 \\
\hline Using clean production technologies & $\begin{array}{l}\text { Zhu, et al., 2005; Rao and Holt, 2005; Kim and Rhee, 2012; } \\
\text { Wang and Dai, } 2018\end{array}$ \\
\hline Warehousing and inventory management & Kim and Rhee, 2012 \\
\hline \multicolumn{2}{|l|}{ Sustainable Procurement } \\
\hline Sustainability policies for suppliers & Esfahbodi et al., 2016 \\
\hline ISO 14001 certification for suppliers & Zhu, et al., 2005; Esfahbodi et al., 2016 \\
\hline Eco-labelling & Esfahbodi et al., 2016; Wang and Dai, 2018 \\
\hline Sustainable raw material or product purchasing & $\begin{array}{l}\text { Min and Galle, 1997; Rao and Holt, 2005; Krause et al., 2009; } \\
\text { Zailani, et al., } 2012\end{array}$ \\
\hline \multicolumn{2}{|l|}{ Digitalization and innovation in purchasing processes } \\
\hline Sustainability monitoring and assessment & Wang and Dai, 2018 \\
\hline Supplier collaboration & Wang and Dai, 2018; Esfahbodi et al., 2016; Paularj et al., 2017 \\
\hline Sustainability audit for suppliers & Wang and Dai, 2018 \\
\hline Supplier meetings & Kim and Rhee, 2012; Wang and Dai, 2018 \\
\hline $\begin{array}{l}\text { Considering environmental and socially responsible aspects in supplier } \\
\text { selection }\end{array}$ & Rao and Holt, 2005; Ortas, et al., 2014; Wang and Dai, 2018 \\
\hline Supplier sustainability training & Rao and Holt, 2005; Wang and Dai, 2018 \\
\hline \multicolumn{2}{|l|}{ Sustainable Distribution } \\
\hline Sustainable packaging & Min and Galle, 1997; Zailani, et al., 2012; Esfahbodi et al., 2016 \\
\hline Distribution emissions rate & Esfahbodi et al., 2016 \\
\hline Digitalization and innovation in the distribution process & Pagell et al., 2004; Esfahbodi et al., 2016 \\
\hline Sustainability meetings and promotions for customers & Wang and Dai, 2018 \\
\hline Energy usage for transportation & Esfahbodi et al., 2016 \\
\hline Environmentally friendly chain of distribution & Rao and Holt, 2005 \\
\hline Cooperation with customers for sustainable design and packaging & Zhu, et al., 2005; Esfahbodi et al., 2016 \\
\hline Socially responsible customer relationship & Wang and Dai, 2018 \\
\hline Social responsibility project & Wang and Dai, 2018 \\
\hline \multicolumn{2}{|l|}{ Reverse Logistics } \\
\hline Recycling investments & Min and Galle, 1997; Zhu and Sarkis, 2007; Pagell et al., 2004 \\
\hline \multicolumn{2}{|l|}{ Recycling project development } \\
\hline Reuse, recycle, and recovery of materials & Zhu, et al., 2005; Kim and Rhee, 2012; Amjad et al., 2017 \\
\hline Renewable energy usage for recovery and recycling & \\
\hline
\end{tabular}

